\title{
VICTORIA KENT Y LOUISE CRANE EN NUEVA YORK. UN EXILIO COMPARTIDO. CARMEN DE LA GUARDIA
}

Madrid: Sílex, 2016, pp. 327. ISBN: 978-84-7737-618-7.

\author{
JUAN IGNACIO GUIJARRO GONZÁLEZ \\ Universidad de Sevilla \\ jiguijarro@us.es
}

Received 31 July 2018

Accepted 18 September 2018

This book is a brilliant contribution to two fields of intellectual inquiry recently consolidated in Spain. On the one hand, the (re)discovery of long-forgotten female figures who in the 1920s and 1930s greatly contributed to Spanish history (or, rather, 'herstory'), as the multimedia project Las sinsombrero has amply demonstrated in recent years by unearthing the cultural and social achievements of exceptional women who were later rendered invisible during the long Francoist dictatorship. On the other hand, the social and cultural exchanges between Spain and the United States, now yearly explored in the international conferences on the "Historical Links between Spain and North America" co-organized every spring by the Franklin Institute of Alcalá de Henares and the City College of New York (CUNY). The list of insightful books on this subject published over the last decade includes Invisible Immigrants. Spaniards in the USA (1868-1945), Geometria y angustia. Poetas españoles en Nueva York, and Contra el olvido. El exilio español en Estados Unidos. Despite its revisionary intent, the latter focuses on the experience of male Spanish intellectuals who moved to the U.S. because of the Civil War (Juan Ramón Jiménez, Américo Castro, or Pedro Salinas), so that women like Victoria Kent are just mentioned in passing.

Therefore, de la Guardia's is a highly successful attempt to counter what at the outset of her book she defines as "un tupido velo en la mayor parte de las historiografias nacionales" (13). She rightly contends that "es necesaria la biografia de Victoria Kent y Louise Crane durante los treinta y siete años que estuvieron juntas (19501987) para romper con la fuerza de las historias nacionales, para 
reivindicar una perspectiva histórica más cosmopolita" (17). As a competent historian, she makes an exhaustive use of archival sources, especially from the Beinecke Library at Yale University, where the Victoria Kent and Louise Crane papers are held. She has also consulted many books in four different languages (English, Spanish, French and Italian), even though they are not often quoted in the main text. Likewise, since many U.S. historical and cultural figures of the 1940s and 1950s are mentioned throughout the text, additional footnotes might have helped contemporary Spanish readers understand their relevance. The author shows her command of the subject and her clarity of ideas by organizing her book in eight solid and coherent chapters, adding at the end a most illuminating section of "Fotografias y documentos" (271-81); however, the conclusions seem rather brief for such wide research. Her style is commendable as well, given that Victoria Kent y Louise Crane en Nueva York is written in a very clear and elegant prose.

Born in Málaga in a middle-class family, Victoria Kent (1892-1987) became a truly pioneering woman in contemporary Spanish history. She was one of the first females to study law in a very sexist country and, despite her progressive views, famously opposed giving Spanish women the right to vote because, under the influence of the Catholic Church, they would vote conservative. Only four days after the Spanish Republic was proclaimed on April 14, 1931, she was appointed to run the national prison system. However, her efforts to modernize it were not well received and she left her position soon in frustration. De la Guardia quotes several times the unkind words that the President of the Spanish Republic, Manuel Azaña, had for Kent: "El consejo de ministros ha logrado por fin ejecutar ( $\mathrm{sic}$ ) a Victoria Kent...en su cargo de directora general ha fracasado. Demasiado humanitaria” (qtd. 80). Such remarks unveil the sexist attitudes that the brilliant women of Kent's generation had to endure, even on the part of progressive politicians like Azaña: "el tono utilizado por los grandes 'varones' de la política y de la cultura variaba, iba desde un paternalismo amistoso y hasta cariñoso, a un desprecio sin matices", in the apt formulation of de la Guardia (201).

When the Spanish Civil War broke out in the summer of 1939 Victoria Kent left for Paris, thinking that the Fascist rebels would be soon defeated. Once the conflict ended, she remained in France, where she penned an autobiographical work, Cuatro años de mi vida (not published in Spain until 1978, once the dictatorship had ended). Like hundreds of leftist intellectuals, she went into political 
exile. After World War Two, she crossed the Atlantic and settled, first in Mexico, and in 1950 she moved to the United States to work at the U.N. headquarters in New York City. In a country with a language she never learned, Victoria Kent began a new period in her fascinating life. She soon met a young and wealthy New York philanthropist, Louise Crane (1913-1997), with whom she established a relationship until her death (terms like "lesbianism" or "homosexuality" are surprisingly absent here). De la Guardia repeatedly underscores that "Victoria y Louise"--as she affectionately refers to them--became active members in a network of female intellectuals that included exceptional women from both the American continent (Mary McCarthy, Marianne Moore, Elizabeth Bishop, Gabriela Mistral, Victoria Ocampo) and Spain (Rosa Chacel, Carmen Conde) who strongly supported each other in midcentury. The relationship between two figures of this brilliant generation-Elizabeth Bishop and the Brazilian architect Lota de Macedo Soares-has been recently portrayed in Bruno Barreto's film Reaching for the Moon.

With Louise Crane's financial backing, in New York Kent tirelessly embarked on the publication of periodicals--Ibérica (1953), Iberica por la libertad (1954-1974)--to support the ideals of the Spanish Republican government in exile, with which she collaborated. However, one of the several ideological paradoxes of Kent's years in the United States is that she was a leftist, while Louis Crane and her family were staunch Republicans. As Carmen de la Guardia rightly notes, politically they were united by their opposition to the USSR, a prevalent feeling in the U.S. during the 1950s, the heyday of the political witch-hunts: "Las dos sentian aversión por el fascismo y también las dos fueron ardorosas antiestalinistas" (120). The author adds that Kent and Crane believed that during the Cold War the United States stood for freedom, which implies that both ignored, first, that it was a harsh time for African Americans (absent from Victoria Kent's world) and, second, that 1950 (the year she settled in New York) brought not only Senator McCarthy's meteoric political rise but also the return to Hollywood of the House UnAmerican Activities Committee (HUAC). Surprisingly, despite her very leftist past in Spain, Kent was never bothered by the investigators, perhaps because of her close association with the strongly Republican Crane family. Another remarkable political paradox is that Kent and Crane are shown holding signs in support of "Ike" during the 1952 presidential campaign in the photograph which 
appears on the book cover; sadly for the Spanish exile, Eisenhower himself happily embraced Franco a few years later, when the geopolitics of the Cold War had suddenly made a dictator an acceptable ally. A third political paradox of note is that, like so many intellectuals of the time, Kent collaborated with cultural organizations which were later revealed to have been secretly funded by the CIA, one of the most startling episodes of the Cold War era.

Chapter 8 is especially appealing to Spanish readers, since it neatly unveils the feeling of disenchantment Kent experienced when she finally returned to a democratic Spain, only to discover that her name had been almost forgotten and that the monarchy had been restored: "la monarquía como forma de estado le repelía. Y en eso se parecía mucho a sus amigos estadounidenses" (242). Even though--as de la Guardia details--she subscribed to and collaborated in El Pais (the newspaper of the new democratic state), she was perceived in her native country as a relic of the past who had nothing to offer: "a Victoria le quedó algún resentimiento... le hubiera gustado colaborar, poner toda su experiencia en funcionamiento" (249)--such disillusionment does not surface during the interview for the Spanish TV program A fondo (1979), which delves mostly on her prison responsabilities and neglects her prolongued exile. Unsurprisingly, she returned to New York, where she died in 1987 at the age of 95, while Louise Crane outlived her ten years, and passed away in 1997.

In Victoria Kent y Louise Crane en Nueva York. Un exilio compartido historian Carmen de la Guardia makes a remarkable contribution to Spanish scholarship. She amply demonstrates that many aspects of Spanish 'herstory' still need to be unearthed and made available to contemporary readers, especially after the massive feminist marches which took place nationwide on March 8 2018, loudly claiming for a greater recognition of women both in the public and the private spheres. Moreover, by researching the lasting and multifaceted relationship between Victoria Kent and Louise Crane, Carmen de la Guardia brings to light one of the countless fascinating topics yet to be addressed regarding the historical, social and cultural exchanges between Spain and the United States.

\section{WORKS CITED}

A fondo. "Entrevista a Victoria Kent". 28 enero 1979.

http://www.rtve.es/alacarta/videos/a-fondo/fondo-victoria- 
kent $/ 3619962 /$ ?pais $=E S$

BARRETO, Bruno, dir. Reaching for the Moon. Imagem Filmes, 2013.

FERNANDEZ, James D., and Luis Argeo. Invisible Immigrants. Spaniards in the USA (1868-1945). White Stone Ridge, 2014.

MARTÍNEZ Carazo, Cristina, and Sebastiaan Faber, eds. Contra el olvido. El exilio español en Estados Unidos. Instituto Franklin, 2010.

NEIRA, Julio, ed. Geometría y angustia. Poetas españoles en Nueva York. Fundación Lara, 2012.

LAS SINSOMBRERO. www.lassinsombrero.com/proyecto crossmedia. 